\title{
Responses of ground-dwelling spider assemblages to changes in vegetation from wet oligotrophic habitats of Western France
}

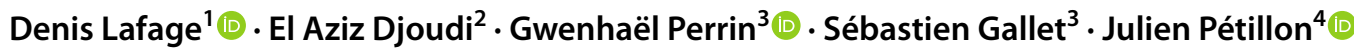

Received: 12 December 2017 / Accepted: 7 February 2019 / Published online: 18 February 2019

(c) The Author(s) 2019

\begin{abstract}
While many arthropod species are known to depend, directly or indirectly, on certain plant species or communities, it remains unclear to what extent vegetation shapes spider assemblages. In this study, we tested whether the activity-density, composition, and diversity of ground-dwelling spiders were driven by changes in vegetation structure. Field sampling was conducted using pitfall traps in bogs, heathlands, and grasslands of Brittany (Western France) in 2013. A total of 8576 spider individuals were identified up to the species level (for a total of 141 species), as well as all plant species in more than 300 phytosociological relevés. A generalised linear model showed that spider activity-density was negatively influenced by mean vegetation height and mean Ellenberg value for moisture. Indices of diversity ( $a, \beta$, and functional diversities) increased with increasing vegetation height and shrub cover. Variables driving spider composition were mean vegetation height, dwarf shrub cover, and low shrub cover (results from a redundancy analysis). Spiders, some of the most abundant arthropod predators, are thus strongly influenced by vegetation structure, including ground-dwelling species. Although later successional states are usually seen as detrimental to local biodiversity in Europe, our results suggest that allowing controlled development of the shrub layer could have a positive impact on the diversity of ground-dwelling spiders.
\end{abstract}

Keywords $\alpha$-Diversity $\cdot \beta$-Diversity $\cdot$ Functional diversity $\cdot$ Araneae $\cdot$ Brittany

Handling Editor: Heikki Hokkanen.

Electronic supplementary material The online version of this article (https://doi.org/10.1007/s11829-019-09685-0) contains supplementary material, which is available to authorized users.

Denis Lafage

lafage.denis@gmail.com

1 Department of Environmental and Life Sciences/Biology, Karlstads Universitet, Fakultet/avdelning, 65188 Karlstad, Sweden

2 EA 7316 Biodiversité et Gestion des Territoires, Université de Rennes 1, 263 Av. du Gal. Leclerc, 35042 Rennes Cedex, France

3 EA 2219 Géoarchitecture, Université de Bretagne Occidentale, CS 93837, 29238 Brest Cedex 3, France

4 Present Address: UMR Ecobio, Université de Rennes 1, 263 Av. du Gal. Leclerc, 35042 Rennes Cedex, France

\section{Introduction}

Globally, increases in plant species diversity or structural heterogeneity are often correlated with an increase in species richness of animals (Southwood et al. 1979; Madden and Fox 1997). The architectural or structural heterogeneity of plants, which is likely correlated with both plant species diversity and productivity (Lawton 1983), can be an important determinant of arthropod diversity and abundance at different trophic levels (Lawton 1983). Many arthropod species depend, directly or not, on vegetation, and it consequently shapes their assemblages (Lewinsohn et al. 2005). This is especially obvious for phytophagous taxa, but has also been shown for other groups using vegetation as shelter or, in the case of spiders, for building their webs. Spider assemblages of vegetation-dwelling and web-building guilds are known to be shaped by vegetation structure, but ground-dwelling spiders are ideal models to test whether vegetation also drives community structure and composition of ground-active predators. While strong relationships have been reported previously between webbuilding spiders and vegetation (e.g. Ávila et al. 2017), other studies reported a weak effect of vegetation structure on spider 
diversity (Rodrigues et al. 2014) and no bottom-up effect of vegetation biomass on spiders (Lassau and Hochuli 2008; Lafage et al. 2014; Sousa-Souto et al. 2014). Ground-dwelling spiders are known to react to several local, abiotic factors, such as $\mathrm{pH}$, disturbance, soil structure, or moisture level (Schaefer 1990; Andersen 1995; Paquin and Coderre 1997; Pétillon et al. 2008). Their abundance and species richness also respond to the depth and complexity of the litter layer (Uetz 1976, 1979a, b; Hurd and Fagan 1992) which are often related to vegetation complexity. For instance, Langellotto and Denno (2004) found a positive relationship between the abundance of hunting spiders and vegetation heterogeneity. Blaum et al. (2009) also found a hump-shaped relationship between both spider abundance and species richness and shrub cover.

Numerous studies have tried to understand the determinants of assemblages' composition and local species richness, i.e. $\alpha$-diversity (e.g. Hendrickx et al. 2007; Jiménez-Valverde et al. 2010; Pétillon et al. 2008). There are fewer studies dealing with $\beta$-diversity and functional diversity (McKnight et al. 2007), but their number has increased in recent years (e.g. Hendrickx et al. 2007; Boieiro et al. 2013; Braaker et al. 2013; Woodcock et al. 2014; Lafage et al. 2015). In this study, we tested whether assemblages of ground-dwelling spiders are shaped by changes in vegetation structure along a successional gradient. We took advantage of the monitoring systems of heathlands and grasslands (i.e. fairly stable habitats where landscape factors are likely less determinant than local factors for spiders: Horváth et al. 2015) in natural reserves to test whether a set of variables derived from the surrounding vegetation was able to predict changes in spider structure and composition at ground level. We therefore chose to investigate assemblage composition, $\alpha$-diversity, $\beta$-diversity, functional diversity, and activity-density. Spider activity-density was expected to be positively influenced by vegetation complexity due to a higher abundance of prey. Species composition and $\alpha$-diversity were expected to be positively influenced by local abiotic factors. Indeed, $\alpha$-diversity describes within-habitat diversity (MacArthur 1965) and is mainly driven by local processes while $\beta$-diversity is generally thought to be driven by both local and landscape factors, the latter being the predominant factor for spiders and carabids (Lafage et al. 2015). We expected a weak or null link between vegetation structure and $\beta$-diversity. Finally, functional diversity was expected to be positively linked to vegetation complexity as this would allow more guilds to coexist (Cardoso et al. 2011).

\section{Materials and methods}

\section{Study sites and habitats}

Samples were taken in three Special Areas of Conservation (SAC) in the inner part of Brittany (Western France) at the head of drainage basins, including two natural reserves: the bogs of Langazel (LG) and the fens and heathlands of Lann Bern and Magoar-Penn Vern (LB) (Fig. 1). Both sites comprise colluvial and peaty plains crossed by streams and alluvial 'streaks.' They are composed of wet oligotrophic habitats including large areas of Ulicion minoris heathlands (EUR 28 4020) and Juncion acutiflori rush pastures (EUR 28 6410), sometimes in a mosaic with small patches of blanket bog communities (Oxycocco palustris-Ericion tetralicis).

Each set of sampling stations had a wide heterogeneity of structural forms resulting from several factors (de Foucault 1984; Clement and Aidoud 2009). While these vegetation forms have close spatial links, they nevertheless belong to different dynamical series mainly determined by edaphic conditions, notably water and trophic level. The diversity of past and current management practices (mostly mowing and grazing at different pressure levels) also explains the diversity of forms as encroachment or regressive vegetation stages.

Wet heaths have a progressive dynamic, ranging from dwarf shrub communities (Ulex gallii-Erica tetralix) to woodlands (Molinia caerulea-Quercus robur), with thickets (Frangula alnus) and birch woodlands (Betula pubescens) as intermediate stages. They are typically dominated by dwarf shrubs and by the Purple moor-grass (Molinia caerulea).

Fen meadows are characterised by low intensity management by mowing or grazing (Caro verticillati-Molinietum caeruleae or Nardo strictae-Juncion squarrosi) and in the most intensive conditions to improved grasslands (Cynosurion cristati or Lolio perennis-Plantaginion majoris). Juncus acutiflorus fens are dominated by rushes and medium herbs. The process of encroachment can lead to a mire characterised by megaphorbs such as Filipendula ulmaria and Angelica sylvestris with structures strongly shaped by Molinia caerulea. Site characteristics are summarised in Tables 1 and 2. Location and type of sampling stations within each site are provided in Online Resource 1.

\section{Sampling design}

Sampling of spiders took place in May and June 2013 over 30 consecutive days using pitfall traps. Each trap was emptied every 2 weeks (two sampling sessions). To compensate for this short sampling duration, we chose to increase spatial effort, as advised by Lövei and Magura (2011). Thus, fortyfive plots were sampled (23 in LB site with 15 grasslands and 8 heathlands and 22 in LG site with 13 grasslands and 12 heathlands, see Online Ressource 1), with four traps per plot $100 \mathrm{~mm}$ diameter, filled with preservative solution (50\% ethylene-glycol, 50\% water) (Schmidt et al. 2006). Traps were placed $10 \mathrm{~m}$ away from each other to avoid interference between traps (Topping and Sunderland 1992). 


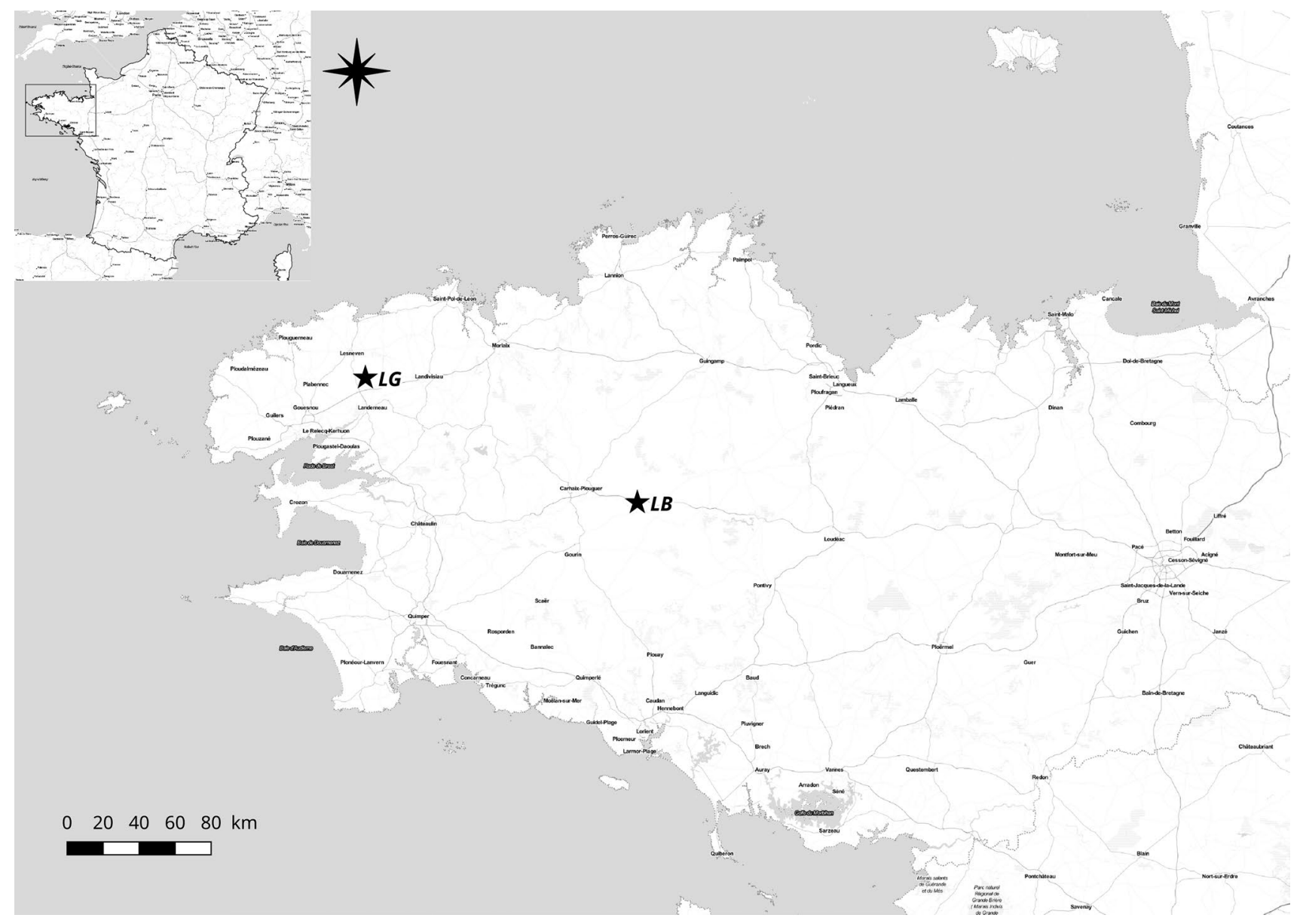

Fig. 1 Site locations. LG: bog of Langazel. LB: fens and heathlands of Lann Bern and Magoar-Penn Vern

Vegetation surveys of $25 \mathrm{~m}^{2}$ plots were conducted at each site to assess vegetation growth-form (dwarf shrub, low shrub, tall shrub, forb, grass, rush, sedge, and tree) cover (\%) following Cristea et al. (2015) and Westhoff and van der Maarel (1978). In addition, five square sub-plots of $0.25 \mathrm{~m}^{2}$ each were set within each plot. In each sub-plot, vascular plant species cover (\%), mean and maximum vegetation height, and litter depth were measured to the nearest $\mathrm{cm}$. Values were then averaged for each plot. Nomenclature follows Platnick (2014) and Gargominy et al. (2015) for spiders and plants, respectively (Online Resources 2 and 3).

\section{Statistical analyses}

Spider activity-density was defined as the mean number of individuals caught per trap. Spider a-diversity was estimated as mean species richness per plot. Spider $\beta$-diversity was estimated using a dissimilarity matrix (corresponding to Sørensen pair-wise dissimilarity) partitioned into its two components-species turnover $\left(\beta_{\mathrm{t}}\right)$ and nestedness $\left(\beta_{\mathrm{n}}\right)$ following Baselga (2010) and using the betapart R package
(Baselga and Orme 2012). Functional diversity (FD) was computed according to Villéger (2008) for spider activitydensity and the Gower dissimilarity matrix was computed based on seven traits: body length (Roberts 1995), seasonality (Harvey et al. 2002), hunting technique, (Uetz et al. 1999) ballooning dispersal (Bell et al. 2005), habitat specialist/generalist (Hänggi et al. 1995), preferred substrate (Buchar et al. 2002), and preferred humidity (Buchar et al. 2002). The species-by-species distance matrix could not be represented in a Euclidean space so, we applied a Cailliez correction (Cailliez 1983). Analyses were performed using the FD package (Laliberté and Legendre 2010; Laliberté et al. 2014).

To investigate ground spider response to abiotic environment and vegetation characteristics, drivers of species assemblages were investigated using constrained analysis. The choice between redundancy analysis (RDA) and constrained correspondence analysis (CCA) was made according to the axis length ( $<3$ or $>4$, respectively) of a detrended correspondence analysis (DCA) (Legendre and Gallagher 2001). Here, we chose a RDA as the first axis length was 
Fig. 2 Projection of spider species and sites on the RDA axes. Circles represent sites. Species names are abbreviated as three first letters of genus and species (see species codes in Online Ressource 2)

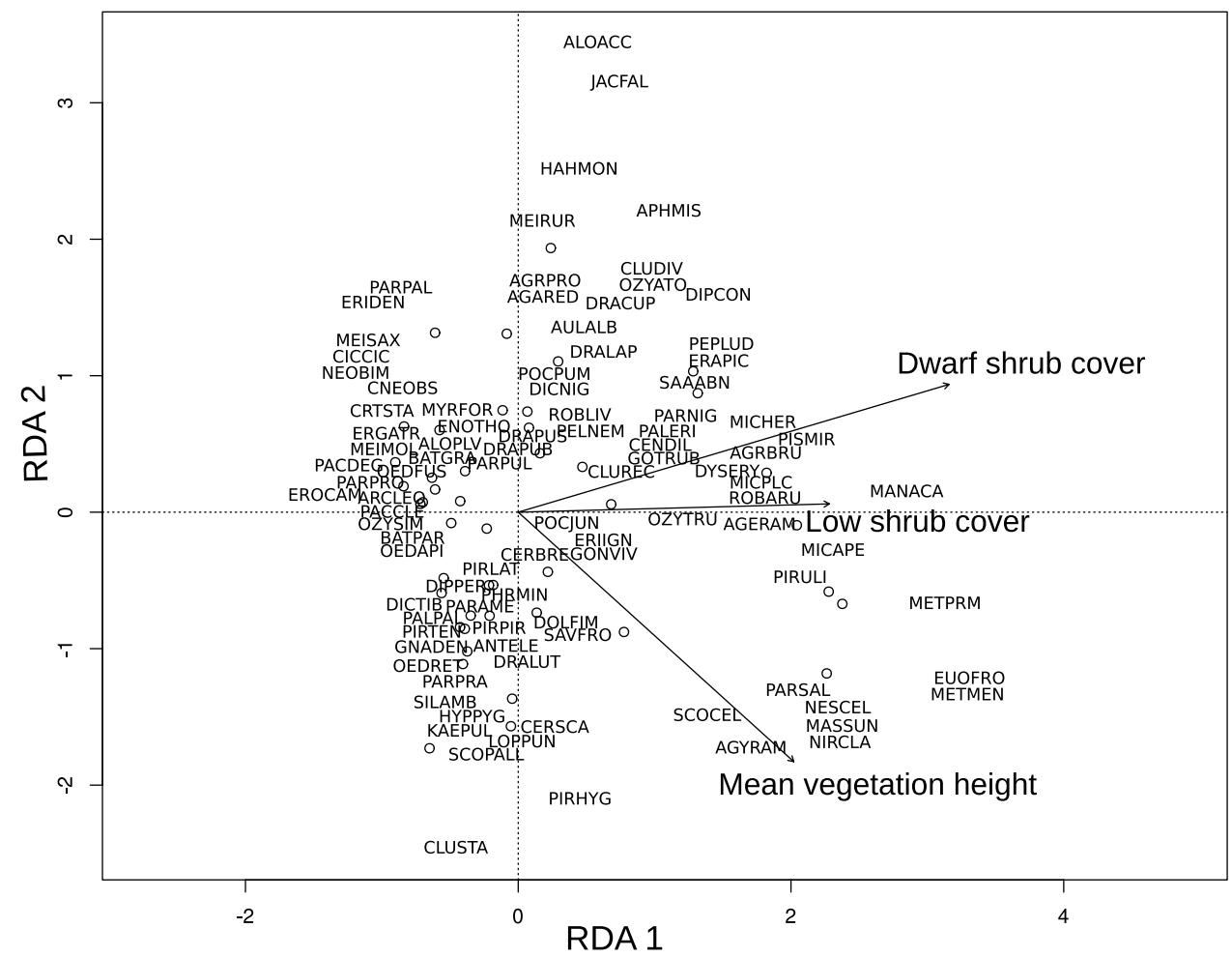

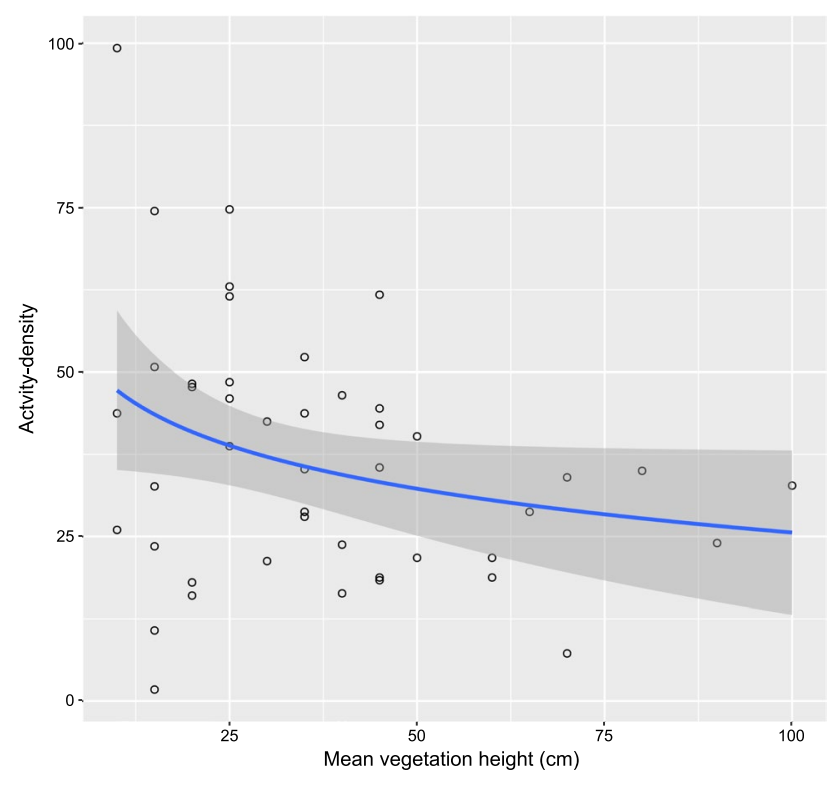

Fig. 3 Spider activity-density as a function of mean vegetation height with $\log$ regression line and $95 \%$ confidence intervals

2.88. Activity-density of all individual species were the response variables. Potential predictor variables included direct measures of vegetation structures, such as vegetation height (mean and max), litter depth, growth-form-type cover (grass, sedge, dwarf shrub, low shrub, forb, rush, and tree), and abiotic variables derived from plant communities using
Ellenberg indicator values (Ellenberg et al. 1992). After correlation tests, only non-significantly or poorly (i.e. $R<0.5$ ) correlated variables were kept in the RDA (see variables in Table 1). Ellenberg indices (moisture $(\mathrm{F})$, nitrogen $(\mathrm{N}), \mathrm{pH}$ (R), light (L), and conductivity (S)) were derived from the phytosociological relevés, using van der Maarel's indices instead of the abundance-dominance coefficient to minimise the weight of dominant species. Moreover, species described in the Ellenberg system as indifferent were ignored (see for e.g. Dzwonko 2002). All other species were kept in the analyses. The Ellenberg values came from Hill et al. (2004) and were corrected for the British Isles. To obtain a more relevant description of the vegetation for the study of spider communities, i.e. illustrating the structure, a simple functional classification of plants adapted from Box (1996) was used. This type of classification results from species growth forms and medium height and includes ten types of plants: trees, tall shrubs, low shrubs, dwarf shrubs, rushes, sedges, grasses, forbs, pteridophytes, and vines. The contribution of the different functional groups was calculated for each secondary plot and the mean contribution was worked out for the entire area, as for vegetation height and litter depth. Litter depth was highly correlated with vegetation height (Spearman test, $R=0.587, P<0.001$ ) and was not included in the analyses despite its importance for ground spiders (Uetz 1979a).

Responses of spider activity-density, $\alpha$-diversity, and functional diversity were tested using generalised linear 
Table 1 Site (LB: fens and heathlands of Lann Bern and MagoarPenn Vern; LG: bogs of Langazel) characteristics summarised by phytosociological association (CARJUN: Caro verticillati-Juncetum acutiflori; CARLAS: Caricetum lasiocarpae (generic); CARMOL:
Caro verticillati-Molinietum caeruleae; CIRFES: Cirsio dissectiScorzoneretum humilis; SCOFES: Scorzonero humilis-Festucetum asperifoliae; SPHERI: Sphagno compacti-Ericetum tetralicis; ULIERI: Ulici gallii-Ericetum tetralicis)

\begin{tabular}{lllllllll}
\hline Site & Association & Mean height & Max height & Dwarf shrub & Forb & Grass & Rush & Tree \\
\hline LB & CARJUN & $45 \pm 37.19$ & $130 \pm 116.33$ & $0.2 \pm 0.4$ & $0.13 \pm 0.09$ & $0.38 \pm 0.37$ & 0.00 & $0.2 \pm 0.36$ \\
& CARMOL & 35.00 & 110.00 & 0.00 & 0.10 & 0.81 & 0.02 & 0.02 \\
& CIRFES & 45.00 & 110.00 & 0.00 & 0.25 & 0.24 & 0.00 & 0.40 \\
& SCOFES & $21.67 \pm 10.41$ & $85 \pm 13.23$ & 0.00 & $0.43 \pm 0.37$ & $0.49 \pm 0.3$ & 0.00 & $0.04 \pm 0.04$ \\
& SPHERI & 65.00 & 140.00 & 0.00 & 0.42 & 0.02 & 0.00 \\
& ULIERI & $38.85 \pm 23.38$ & $78.85 \pm 34.89$ & $0.19 \pm 0.23$ & $0.09 \pm 0.14$ & $0.48 \pm 0.26$ & $0.02 \pm 0.05$ & $0.14 \pm 0.27$ \\
LG & CARJUN & $23.33 \pm 12.11$ & $64.17 \pm 32.16$ & $0.06 \pm 0.15$ & $0.18 \pm 0.19$ & $0.65 \pm 0.23$ & $0.01 \pm 0.02$ & $0.05 \pm 0.06$ \\
& CARLAS & 15.00 & 25.00 & 0.00 & 0.02 & 0.66 & 0.00 \\
& CARMOL & $53.33 \pm 22.73$ & $172.5 \pm 171.4$ & $0.36 \pm 0.35$ & $0.02 \pm 0.04$ & $0.5 \pm 0.33$ & $0.09 \pm 0.1$ & $0.02 \pm 0.04$ \\
& CIRFES & $30 \pm 5$ & $58.33 \pm 15.28$ & $0.16 \pm 0.28$ & $0.05 \pm 0.06$ & $0.59 \pm 0.23$ & 0.00 \\
& SCOFES & $28.33 \pm 20.21$ & $63.33 \pm 16.07$ & $0.3 \pm 0.27$ & $0.13 \pm 0.23$ & $0.33 \pm 0.13$ & $0.06 \pm 0.09$ & $0.15 \pm 0.2$ \\
& SPHERI & 45.00 & 55.00 & 0.36 & 0.02 & 0.55 & 0.00 \\
& ULIERI & 40.00 & $82.5 \pm 3.54$ & 0.00 & $0.23 \pm 0.11$ & $0.55 \pm 0.13$ & 0.00 & 0.01 \\
\end{tabular}

Mean height: mean \pm SD vegetation height $(\mathrm{cm})$, Max height: mean \pm SD maximum vegetation height $(\mathrm{cm})$. Values for Dwarf shrub, Forb, Grass, Rush, and Tree are mean \pm SD \% cover

Table 2 Mean \pm SD Ellenberg index values by site (LB: fens and heathlands of Lann Bern and Magoar-Penn Vern; LG: bogs of Langazel) and association (CARJUN: Caro verticillati-Juncetum acutiflori; CARLAS: Caricetum lasiocarpae (generic);

CARMOL: Caro verticillatiMolinietum caeruleae; CIRFES: Cirsio dissecti-Scorzoneretum humilis; SCOFES: Scorzonero humilis-Festucetum asperifoliae; SPHERI: Sphagno compacti-Ericetum tetralicis; ULIERI: Ulici gallii-Ericetum tetralicis)

\begin{tabular}{lllllll}
\hline Site & Association & $L$ & $F$ & $R$ & $N$ & $S$ \\
\hline LB & CARJUN & $6.83 \pm 0.35$ & $6.87 \pm 0.45$ & $3.83 \pm 0.95$ & $2.89 \pm 0.47$ & $0.01 \pm 0.02$ \\
& CARMOL & 7.32 & 7.18 & 4.08 & 2.22 & 0.06 \\
& CIRFES & 7.19 & 6.98 & 4.89 & 3.59 & 0.06 \\
& SCOFES & $6.68 \pm 0.28$ & $6.25 \pm 0.42$ & $4.53 \pm 0.42$ & $3.45 \pm 0.38$ & $0.18 \pm 0.03$ \\
& SPHERI & 6.08 & 6.29 & 4.52 & 4.04 & 0.09 \\
& ULIERI & $7.13 \pm 0.29$ & $6.94 \pm 0.63$ & $3.45 \pm 1.12$ & $2.54 \pm 0.83$ & $0.04 \pm 0.08$ \\
LG & CARJUN & $7.18 \pm 0.4$ & $7.17 \pm 0.52$ & $3.84 \pm 0.89$ & $2.59 \pm 0.61$ & $0.06 \pm 0.04$ \\
& CARLAS & 7.43 & 7.48 & 3.79 & 2.3 & 0 \\
& CARMOL & $6.95 \pm 0.33$ & $6.86 \pm 0.69$ & $3.28 \pm 0.91$ & $2.47 \pm 0.65$ & $0.06 \pm 0.11$ \\
& CIRFES & $7.39 \pm 0.21$ & $7.18 \pm 0.86$ & $3.63 \pm 1.48$ & $2.56 \pm 0.96$ & $0.13 \pm 0.17$ \\
& SCOFES & $7.29 \pm 0.18$ & $7.42 \pm 0.32$ & $3.51 \pm 1.35$ & $2.62 \pm 0.95$ & $0.08 \pm 0.09$ \\
& SPHERI & 7.39 & 6.93 & 3.32 & 1.95 & 0 \\
& ULIERI & $6.99 \pm 0.2$ & $6.75 \pm 0.58$ & $4.14 \pm 0.76$ & $2.84 \pm 0.81$ & $0.06 \pm 0.08$ \\
\hline
\end{tabular}

$L$ mean Ellenberg index value for light, $F$ mean Ellenberg index value for moisture, $R$ mean Ellenberg index value for $\mathrm{pH}, N$ mean Ellenberg index value for nitrogen, $S$ mean Ellenberg index value for conductivity models (GLMs). For activity-density, we used binomialnegative distribution with a logit link. For $\alpha$-diversity and functional diversity, we assumed a Gaussian distribution and used a linear model. Relevant variables were selected using a stepwise model selection by AIC (Akaike 1974).

To identify the variables significantly influencing spider $\beta$-diversity, we performed a multiple regression analysis on the distance matrix of predictors (MRM) following the methods outlined in Legendre et al. (1994) using the ecodist R package (Goslee and Urban 2007). Predictors were the same as for RDA and GLMs. All statistical analyses were performed using R 3.2.3 (R Core Team 2015).

\section{Results}

A total of 8576 spider individuals belonging to 141 species (see Online Ressource 2) were caught, with a high $(93.38 \%)$ ratio of adult spiders. Assemblages were dominated by two lycosids (Pirata latitans and Pardosa 
pullata representing $24 \%$ and $23 \%$ of adult individuals, respectively).

RDA on spider assemblages was significant $\left(F_{14,30}=\right.$ 1.63, $\mathrm{df}=14, P<0.001)$ and explained $43.3 \%$ of the total variance, and the four first axes of the RDA were significant (respectively $F_{1,30}=7.42, \mathrm{df}=1, P<0.001 ; F_{1,30}=3.87$, $\mathrm{df}=1, P=0.001 ; F_{1,30}=2.23, \mathrm{df}=1, P=0.001 ; F_{1,30}=1.94$, $\mathrm{df}=1, P=0.008)$. Variables explaining spider composition were mean vegetation height $\left(F_{1,30}=3.89, \mathrm{df}=1, P=0.001\right)$, dwarf shrub cover $\left(F_{1,30}=5.07, \mathrm{df}=1, P=0.001\right)$, and low shrub cover $\left(F_{1,30}=1.79, \mathrm{df}=1, P=0.041\right)$ (Fig. 2).

Spider activity-density was significantly and negatively influenced by mean vegetation height and the mean Ellenberg value for moisture (Table 3, Fig. 3). Spider a-diversity was significantly and positively influenced by dwarf shrub and forb cover (Table 3, Fig. 4). It was also positively influenced by Ellenberg index values for light and negatively by Ellenberg index values for moisture (Table 3). Spider functional diversity was positively influenced by dwarf shrub cover and Ellenberg index values for conductivity (Table 3). MRM was significant $\left(P=0.007, R^{2}=0.13\right)$. Spi$\operatorname{der} \beta$-diversity was significantly and positively influenced by mean vegetation height and by Ellenberg index value for $\mathrm{pH}$, and negatively influenced by Ellenberg index value for nitrogen (Table 3).
Table 3 Significant explicative variables kept by the step-AIC on the results of the general linear model (GLM) on activity-density, $\alpha$-diversity and functional diversity (FD) of spiders, and significant explicative variables from the multiple regression on distance matrices (MRM) on spider $\beta$-diversity

\begin{tabular}{llll}
\hline & Variables kept & Statistics & Sign \\
\hline Activity-density & Mean height & $z=-2.747 ; P=0.006$ & - \\
& Ellenberg F & $z=-2.25 ; P=0.024$ & - \\
$\alpha$-Diversity & Dwarf shrub & $z=2.18 ; P=0.029$ & + \\
& Forb & $z=2.06 ; P=0.039$ & + \\
& Ellenberg L & $z=2.53 ; P=0.011$ & + \\
$\beta$ & Ellenberg F & $z=-2.01 ; P=0.044$ & - \\
$\beta$ & Mean height & $P=0.004$ & + \\
& Ellenberg R & $P=0.031$ & + \\
FD & Ellenberg N & $P=0.020$ & - \\
& Dwarf shrub & $z=2.13 ; P=0.040$ & + \\
& Ellenberg S & $z=2.34 ; P=0.025$ & + \\
\hline
\end{tabular}

(Ellenberg L: mean Ellenberg value for light; Ellenberg F: mean Ellenberg value for moisture; Ellenberg R: mean Ellenberg value for $\mathrm{pH}$; Ellenberg N: mean Ellenberg value for nitrogen, $\mathrm{S}$ : mean Ellenberg value for conductivity)

\section{Discussion}

Our results suggest that the spider assemblages studied were strongly influenced by vegetation structure, even when considering ground-dwelling species. We found spider
Fig. 4 Spider $\alpha$-diversity as a function of dwarf shrub cover with $\log$ regression line and 95\% confidence intervals

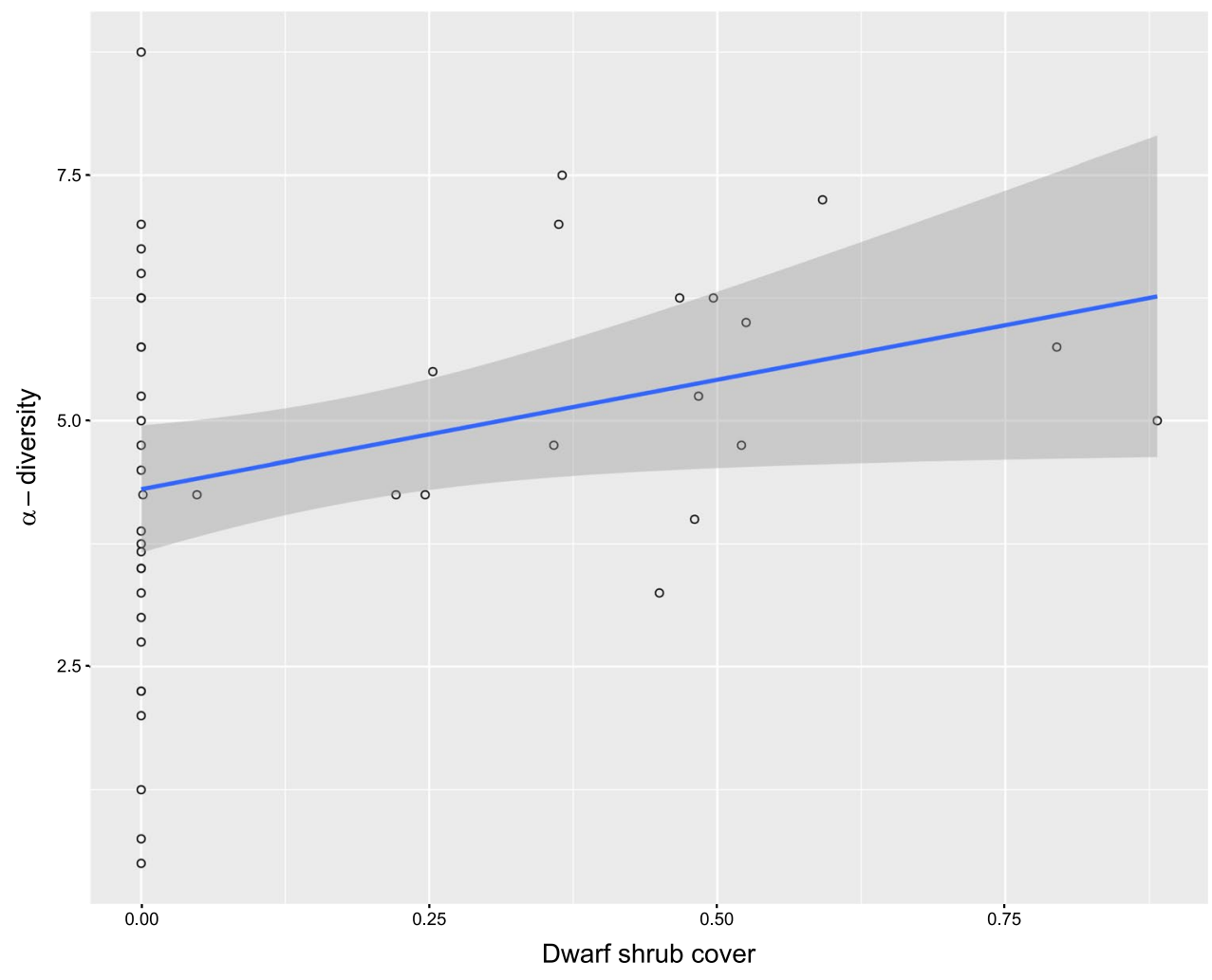


activity-density to be negatively influenced by vegetation height. This is in opposition with previous studies dealing with simplification of vegetation structure at both habitat and within-plant scales (see Langellotto and Denno 2004 for a meta-analysis), which found that increasing habitat complexity results in significant increases in arthropod, especially hunting and web-building spider, abundance. Predators may indeed aggregate in complex habitats because they find a higher abundance of prey, refuge from predation, better conditions for prey localisation and capture, a favourable microclimate, and alternative resources (Langellotto and Denno 2004). Nevertheless, results for ground-dwelling spiders are usually less clear. For instance, Hurd and Fagan (1992) did not find any clear effect of succession (from herbaceous to woody communities) on spider abundance. In our dataset, vegetation height was highly and positively correlated to litter depth. Uetz (1979a, b) found that the activity-density of Lycosidae (that were the most abundant spiders in our study) was negatively influenced by increasing litter depth. Consequently, the negative relationship observed between vegetation height and spider activity-density is most likely the consequence of changes in litter characteristics rather than in vegetation structure. It is important to note that spider activity-density is dependent on individuals' mobility. Changes in micro-climatic and structural conditions of habitats modified by vegetation height (Griffin and Yeargan 2002; Langellotto and Denno 2004) are actually known to affect the mobility of individuals, and therefore their catchability (which was already mentioned by Uetz 1976; Topping and Sunderland 1992; Lang 2000). Thus, the hypothesis that the negative link observed between spider activity-density and vegetation height is the consequence of a sampling bias cannot be rejected.

Spider activity-density was also negatively influenced by moisture, which is in accordance with previous findings (Uetz 1979b). In a literature review, Wise (1995) suggested that the abundance of spiders depends on three variables: wind, moisture, and temperature. More recently, Entling et al. (2007) and Lambeets et al. (2008) showed moisture to be an important driver of riparian spider activity-density.

Spider assemblages were best explained by variables reflecting vegetation structure, and more specifically vegetation closure and complexity (mean vegetation height, dwarf shrub cover, and low shrub cover). The importance of these variables is confirmed by the fact that we found dwarf shrub and forb cover to be positively related to a-diversity and mean vegetation height to increasing $\beta$-diversity. According to Entling et al. (2007), spider assemblages are mainly related to habitat type and depend on the shading, as well as the moisture, of habitats. Shading is obviously related to the development of shrubs and we logically found spider a-diversity to be positively influenced by light. Thus, changes in vegetation structure and shading may explain our results. Indeed, the role of habitat structure in itself has repeatedly been shown to determine the species richness of spiders (more so than the age of habitats, for example: Gibson et al. 1992; Hurd and Fagan 1992; Pétillon 2014). Greater vegetation complexity is likely to allow more species to coexist by reducing inter-specific competition (Marshall and Rypstra 1999; Wise 2006). Vegetation closure is also positively linked to litter depth (e.g. Pétillon et al. 2008), which has been identified as a key variable explaining spider assemblages (Uetz 1979a, b).

We found spider $\beta$-diversity was positively influenced by mean vegetation height and, therefore, vegetation closure. Spider $\beta$-diversity is considered higher in open habitats than in forests (Entling et al. 2007), and shading has long been identified as a major driver of $\beta$-diversity among habitats (MacArthur 1965). Nevertheless, at the beginning of the succession toward forested stages, the development of tall grasses and shrubs may increase $\beta$-diversity by providing new habitats for spiders. This is especially true for web-building species, but our results suggest this could also be true for ground-dwelling spiders. Studies dealing with small-scale drivers of arthropod $\beta$-diversity are scarce but compositional heterogeneity of spiders between samples is higher in young forest stands (Niemala et al. 1996). More recently, Sobek et al. (2009) found that habitat heterogeneity induced by tree diversity increases the $\beta$-diversity of true bugs. Spider $\beta$-diversity was also influenced positively by $\mathrm{pH}$ and negatively by nutrient level. Forestation of moorland is often characterised by an increase in $\mathrm{pH}$, nutrient level, and conductivity (Kampichler and Platen 2004). Thus, spider $\beta$-diversity seems to be positively influenced by the abiotic consequences of shrub and tree development.

Functional diversity was also positively influenced by dwarf shrub cover and conductivity, indicating that the impact of vegetation closure is linked to modification of vegetation structure and abiotic changes induced by it. This result is not surprising as functional diversity is considered more sensitive to environmental change than taxonomic diversity (Cadotte et al. 2009; Schirmel et al. 2012; Woodcock et al. 2014). Indeed, taxonomic diversity often remains relatively stable regardless of vegetation changes (Brown et al. 2001; Schirmel et al. 2012) contrary to functional diversity (Schirmel et al. 2012). This is also in accordance with Schirmel et al. (2016), who found functional diversity to be higher in woody than herbaceous sites.

\section{Conclusion}

Spider community assemblages appear to be driven by factors clearly linked to characteristics of vegetation and edaphic conditions such as vegetation height, shrub cover, $\mathrm{pH}$, and soil richness. These parameters vary not only with 
vegetation dynamics but also according to vegetation management. In Europe, and especially in France, management strategies considered encroachment_-and more generally natural dynamics - as negative trends for the conservation of agro-pastoral habitats leading to a loss of diversity and to the regression of their specific components. Management of wet heathlands and Juncus acutiflorus fens responds to this logic by increasing dwarf shrubby and herbaceous structures of vegetal communities through cutting or grazing operations. Conversely, our results suggest that allowing a controlled development of the shrub layer could have a positive impact on the diversity of certain groups such as ground-dwelling spiders. This clearly illustrates that "ecological value" of habitats and resulting management choices should be made using a pluritaxonomic approach. However, these results do not allow us to reach a conclusion on the value of a particular management strategy according to the type of habitat. Further analyses are consequently needed to test for the effect of management modalities and habitat types.

Acknowledgements We would like to thank Angélique Mangenot, Sandrine Alary (Association de Langazel), Pierrick Pustoc'h, and Mélanie Ulliac (A.M.V. Lann Bern et Magoar) for field assistance, Cyril Courtial for help in species identification, and Farid Bensettiti and Lise Maciejewski (M.N.H.N.) for useful comments. This study was funded by "Région Bretagne", French Ministry of Ecology, Sustainable Development and Energy and General Councils of Côtes d'Armor, Morbihan, Ille-et-Vilaine and Finistère.

OpenAccess This article is distributed under the terms of the Creative Commons Attribution 4.0 International License (http://creativeco mmons.org/licenses/by/4.0/), which permits unrestricted use, distribution, and reproduction in any medium, provided you give appropriate credit to the original author(s) and the source, provide a link to the Creative Commons license, and indicate if changes were made.

\section{References}

Akaike H (1974) A new look at the statistical model identification. IEEE Trans Automat Contr 19:716-723

Andersen AN (1995) Measuring more of biodiversity: genus richness as a surrogate for species richness in Australian ant faunas. Bio Cons 73:39-43

Ávila AC, Stenert C, Rodrigues ENL, Maltchik L (2017) Habitat structure determines spider diversity in highland ponds. Ecol Res 32:359-367. https://doi.org/10.1007/s11284-017-1442-7

Baselga A (2010) Partitioning the turnover and nestedness components of beta diversity. Glob Ecol Biogeogr 19:134-143. https://doi.org /10.1111/j.1466-8238.2009.00490.x

Baselga A, Orme CDL (2012) betapart: an R package for the study of beta diversity. Methods Ecol Evol 3:808-812. https://doi. org/10.1111/j.2041-210X.2012.00224.x

Bell JR, Bohan DA, Shaw EM, Weyman GS (2005) Ballooning dispersal using silk: world fauna, phylogenies, genetics and models. Bull Entomol Res 95:69-114. https://doi.org/10.1079/BER2004350

Blaum N, Seymour C, Rossmanith E, Schwager M, Jeltsch F (2009) Changes in arthropod diversity along a land use driven gradient of shrub cover in savanna rangelands: identification of suitable indicators. Biodiversity and Conservation 18:1187-1199. https:// doi.org/10.1007/s10531-008-9498-x

Boieiro M, Carvalho JC, Cardoso P et al (2013) Spatial factors play a major role as determinants of endemic ground beetle Beta diversity of Madeira island laurisilva. PLoS ONE 8:1-9. https://doi. org/10.1371/journal.pone.0064591

Box EO (1996) Plant functional types and climate at the global scale. J Veg Sci 7:309-320. https://doi.org/10.2307/3236274

Braaker S, Ghazoul J, Obrist MK, Moretti M (2013) Habitat connectivity shapes urban arthropod communities - the key role of green roofs. Ecology 95:1010-1021. https://doi.org/10.1890/13-0705.1

Brown JH, Ernest SKM, Parody JM, Haskell JP (2001) Regulation of diversity: maintenance of species richness in changing environments. Oecologia 26:321-332

Buchar J, Růžička V, Merrett P (2002) Catalogue of spiders of the Czech Republic, Peres, Praha

Cadotte MW, Cavender-Bares J, Tilman D, Oakley TH (2009) Using phylogenetic, functional and trait diversity to understand patterns of plant community productivity. PLoS ONE 4:e5695. https://doi.org/10.1371/journal.pone.0005695

Cailliez F (1983) The analytical solution of the additive constant problem. Psychometrika 48:305-310

Cardoso P, Pekár S, Jocqué R, Coddington JA (2011) Global patterns of guild composition and functional diversity of spiders. PLoS ONE 6:e21710. https://doi.org/10.1371/journal.pone.0021710

Clement C, Aidoud A (2009) Resistance against eutrophication based on 40-year diachronic study (1966-2006) on marginal wetlands of oligotrophic shallow lakes in south-west of France. FR2116. Rapport du projet europeen Eurolimpacs. 27

Cristea V, Gafta D, Pedrotti F (2015) Fitosociologia. TEMI Editrice, Trento

de Foucault B (1984) Systémique, structure et synsystématique des prairies hygrophiles des plaines atlantiques françaises. Tome I

Dzwonko Z (2002) Assessment of light and soil conditions in ancient and recent woodlands by Ellenberg indicator values: using Ellenberg indicator values in woodlands. J Appl Ecol 5:942-951

Ellenberg H, Weber HE, Düll R et al (1992) Zeigerwerte von Pflanzen in Mitteleuropa, 2nd edn. Scr Geobot 18:1-258

Entling W, Schmidt M, Bacher S et al (2007) Niche properties of Central European spiders: shading, moisture and the evolution of the habitat niche. Glob Ecol Biogeogr 16:440-448. https:// doi.org/10.1111/j.1466-8238.2006.00305.x

Gargominy O, Tercerie S, Régnier C et al (2015) TAXREF v9.0, référentiel taxonomique pour la France: méthodologie, mise en œuvre et diffusion. Muséum national d'Histoire naturelle, Paris (France). Rapport SPN 2015-64. p 126

Gibson CWD, Hambler C, Brown VK (1992) Changes in spider (Araneae) assemblages in relation to succession and grazing management. J Appl Ecol 29:132-142

Goslee SC, Urban DL (2007) The ecodist package for dissimilaritybased analysis of ecological data. J Stat Softw 22:1-19

Griffin ML, Yeargan KV (2002) Factors potentially affecting oviposition site selection by the lady beetle Coleomegilla maculata (Coleoptera: Coccinellidae). Environ Entomol 31:112-119

Hänggi A, Stöckli E, Nentwig W (1995) Habitats of central European spiders. Miscellanea Faunistica Helvetiae 4:1-460

Harvey PR, Nellist DR, Telfer MG (2002) Provisional atlas of British spiders (Arachnida, Araneae). Biological Records Center, Huntington

Hendrickx F, Maelfait J-P, Van Wingerden W et al (2007) How landscape structure, land-use intensity and habitat diversity affect components of total arthropod diversity in agricultural landscapes. J Appl Ecol 44:340-351. https://doi.org/10.111 $1 / \mathrm{j} .1365-2664.2006 .01270 . x$

Hill M, Preston C, Roy D (2004) Attributes of British and Irish plants: status, size, life history, geography and habitats for use 
in connection with the New Atlas of the British and Irish flora. Centre for Ecology and Hydrology, Huntingdon

Horváth R, Magura T, Szinetár C et al (2015) In stable, unmanaged grasslands local factors are more important than landscape-level factors in shaping spider assemblages. Agric Ecosyst Environ 208:106-113

Hurd LE, Fagan WF (1992) Cursorial spiders and succession: age or habitat structure? Oecologia 92:215-221

Jiménez-Valverde A, Baselga A, Melic A, Txasko N (2010) Climate and regional beta-diversity gradients in spiders: dispersal capacity has nothing to say? Insect Conserv Divers 3:51-60. https:// doi.org/10.1111/j.1752-4598.2009.00067.x

Kampichler C, Platen R (2004) Ground beetle occurrence and moor degradation: modelling a bioindication system by automated decision-tree induction and fuzzy logic. Ecol Indic 4:99-109. https://doi.org/10.1016/j.ecolind.2004.01.001

Lafage D, Secondi J, Georges A et al (2014) Satellite-derived vegetation indices as surrogate of species richness and abundance of ground beetles in temperate floodplains. Insect Conserv Divers 7:327-333. https://doi.org/10.1111/icad.12056

Lafage D, Maugenest S, Bouzillé J-B, Pétillon J (2015) Disentangling the influence of local and landscape factors on alpha and beta diversities: opposite response of plants and ground-dwelling arthropods in wet meadows. Ecol Res 30:1025-1035. https://doi.org/10.1007/ s11284-015-1304-0

Laliberté E, Legendre P (2010) A distance-based framework for measuring functional diversity from multiple traits. Ecology 91:299-305

Laliberté E, Legendre P, Shipley B (2014) FD: measuring functional diversity from multiple traits, and other tools for functional ecology. R Package Version 1:0-12

Lambeets K, Vandegehuchte ML, Maelfait J-P, Bonte D (2008) Understanding the impact of flooding on trait-displacements and shifts in assemblage structure of predatory arthropods on river banks. J Anim Ecol 77:1162-1174. https://doi.org/10.111 1/j.1365-2656.2008.01443.x

Lang A-G (2000) The pitfalls of pitfalls: a comparison of pitfall trap catches and absolute density estimates of epigeal invertebrate predators in arable land. J Pest Sci 73:99-106. https://doi.org/10.1007/ BF02956438

Langellotto GA, Denno RF (2004) Responses of invertebrate natural enemies to complex-structured habitats: a meta-analytical synthesis. Oecologia 139:1-10. https://doi.org/10.1007/s00442-004-1497-3

Lassau SA, Hochuli DF (2008) Testing predictions of beetle community patterns derived empirically using remote sensing. Divers Distrib 14:138-147. https://doi.org/10.1111/j.1472-4642.2007.00438.x

Lawton JH (1983) Plant Architecture and the Diversity of Phytophagous Insects. Annu Rev Entomol 28:23-39. https://doi.org/10.1146/annur ev.en.28.010183.000323

Legendre P, Gallagher E (2001) Ecologically meaningful transformations for ordination of species data. Oecologia 129:271-280. https://doi. org/10.1007/s004420100716

Legendre P, Lapointe F, Casgrain P (1994) Modeling brain evolution from behaviour: a permutational regression approach. Evolution 48(5):1487-1499

Lewinsohn TM, Novotny V, Basset Y (2005) Insects on plants: diversity of herbivore assemblages revisited. Annu Rev Ecol Evol S 36:597-620

Lövei GL, Magura T (2011) Can carabidologists spot a pitfall? The nonequivalence of two components of sampling effort in pitfall-trapped ground beetles (Carabidae). Community Ecol 12:18-22. https://doi. org/10.1556/ComEc.12.2011.1.3

MacArthur RH (1965) Patterns of species diversity. Biol Rev 40:510-533

Madden KE, Fox BJ (1997) Arthropods as indicators of the effects of flouride pollution on the succession following sand mining. J Appl Ecol 34:1239-1256
Marshall SD, Rypstra AL (1999) Spider competition in structurally simple ecosystems. J Arachnol 27:343-350. https://doi.org/10.2307/37060 06

McKnight MW, White PS, McDonald RI et al (2007) Putting betadiversity on the map: broad-scale congruence and coincidence in the extremes. PLoS Biol 5:e272. https://doi.org/10.1371/journ al.pbio.0050272

Niemala J, Haila Y, Punttila P (1996) The importance of small-scale heterogeneity in boreal forests: variation in diversity in forest-floor invertebrates across the succession gradient. Ecography 19:352-368. https://doi.org/10.1111/j.1600-0587.1996.tb01264.x

Paquin P, Coderre D (1997) Changes in soil macroarthropod communities in relation to forest maturation through three successional stages in the Canadian boreal forest. Oecologia 12:104-111

Pétillon J, Georges A, Canard A et al (2008) Influence of abiotic factors on spider and ground beetle communities in different salt-marsh systems. Basic Appl Ecol 9:743-751. https://doi.org/10.1016/j. baae.2007.08.007

Pétillon J, Potier S, Carpentier A, Garbutt A (2014) Evaluating the success of managed realignment for the restoration of salt marshes: lessons from invertebrate communities. Ecol Eng 69:70-75. https ://doi.org/10.1016/j.ecoleng.2014.03.085

Platnick NI (2014) The world spider catalog, version 15. American Museum of Natural History, New York

R Core Team (2015) R: a language and environment for statistical computing. R Foundation for Statistical Computing, Vienna

Rodrigues ENL, Mendonça MD, Costa-Schmidt LE (2014) Spider diversity responds strongly to edge effects but weakly to vegetation structure in riparian forests of Southern Brazil. ArthropodPlant Interact 8:123-133

Roberts MJ (1995) The spiders of Britain and Northern Europe. Harper Collins Publisher, London

Schaefer M (1990) The soil fauna of a beech forest on limestone: trophic structure and energy budget. Oecologia 82:128-136

Schirmel J, Blindow I, Buchholz S (2012) Life-history trait and functional diversity patterns of ground beetles and spiders along a coastal heathland successional gradient. Basic Appl Ecol 13(7):606-614. https://doi.org/10.1016/j.baae.2012.08.015

Schirmel J, Thiele J, Entling MH, Buchholz S (2016) Trait composition and functional diversity of spiders and carabids in linear landscape elements. Agric Ecosyst Environ 235:318-328. https://doi. org/10.1016/j.agee.2016.10.028

Schmidt MH, Clough Y, Schulz W et al (2006) Capture efficiency and preservation attributes of different fluids in pitfall traps. $\mathbf{J}$ Arachnol 34:159-162. https://doi.org/10.1636/T04-95.1

Sobek S, Goßner MM, Scherber C et al (2009) Tree diversity drives abundance and spatiotemporal $\beta$-diversity of true bugs (Heteroptera). Ecol Entomol 34:772-782. https://doi.org/10.111 1/j.1365-2311.2009.01132.x

Sousa-Souto L, Santos EDS, Figueiredo PMFG et al (2014) Is there a bottom-up cascade on the assemblages of trees, arboreal insects and spiders in a semiarid Caatinga? Arthropod Plant Interact 8:581-591. https://doi.org/10.1007/s11829-014-9341-0

Southwood TRE, Brown VK, Reader PM (1979) The relationships of plant and insect diversities in succession. Biol J Linn Soc $12: 327-348$

Topping C, Sunderland KD (1992) Limitations to the pitfall traps in ecological-studies exemplified by a study of spiders in a field of winter-wheat. J Appl Ecol 29:485-491

Uetz GW (1976) Gradient analysis of spider communities in a streamside forest. Oecologia 22:373-385

Uetz GW (1979a) The influence of variation in litter habitats on spider communities. Oecologia 40:29-42

Uetz GW (1979b) The effect of flooding on floodplain arthropod distribution, abundance and community structure. Am Midl Nat 101:286-299 
Uetz GW, Halaj J, Cady AB (1999) Guild Structure of Spiders in Major Crops. J Arachnol 27:270-280

Villéger S (2008) New multidimensional functional diversity indices for a multifaceted framework in functional ecology. Ecology 89:2290-2301

Westhoff V, van der Maarel E (1978) The Braun-Blanquet approach. In: Whittaker RH (ed) Classification of plant communities. Junk, The Hague

Wise DH (1995) Spiders in ecological webs. Cambridge University Press, Cambridge

Wise DH (2006) Cannibalism, food limitation, intraspecific competition, and the regulation of spider populations. Annu Rev Entomol
51:441-465. https://doi.org/10.1146/annurev.ento.51.110104.15094

Woodcock BA, Harrower C, Redhead J et al (2014) National patterns of functional diversity and redundancy in predatory ground beetles and bees associated with key UK arable crops. J Appl Ecol 51(1):142151. https://doi.org/10.1111/1365-2664.12171

Publisher's Note Springer Nature remains neutral with regard to jurisdictional claims in published maps and institutional affiliations. 